\title{
Serum pepsinogen I and II concentrations and IgG antibody to Helicobacter pylori in dyspeptic patients
}

\author{
G Biasco, G M Paganelli, D Vaira, J Holton, G Di Febo, S Brillanti, M Miglioli, \\ L Barbara, I M Samloff
}

\begin{abstract}
Aims-To investigate the association between histologically confirmed gastritis, carriage of Helicobacter pylori and pepsinogen (PG) I and PG II concentrations.

Methods-Prospective study of 81 dyspeptic patients undergoing upper gastrointestinal endoscopy was made. The extent of gastric mucosal inflammation and the presence of $H$ pylori was determined, and serology to evaluate PG I and II concentrations and IgG titres to $H$ pylori was carried out.

Results-The presence of $H$ pylori was strongly correlated with high IgG antibody titres to $H$ pylori and gastritis. Patients who were $H$ pylori positive had significantly higher PG I and PG II concentrations and a significantly lower PG I:PG II ratio than patients who were negative for $H$ pylori. In 13 patients with duodenal ulcer and $H$ pylori positive gastritis serum PG I concentrations were significantly higher than in $H$ pylori positive patients without duodenal ulcer. Significant correlations were found between the age of patients and serum PG II, the PG I:PG II ratio, IgG antibodies to $H$ pylori, the severity of body gastritis and $H$ pylori infection, and between the degree of gastritis in the body of the stomach and the PG II concentration.

Conclusions-Serum PG I and II concentrations, together with a fall in the PG I:PG II ratio, could be used as predictors of $H$ pylori infection as well as serum IgG antibody response to $H$ pylori.
\end{abstract}

(F Clin Pathol 1993;46:826-828)

A strong association is now recognised between the presence of Helicobacter pylori in gastric mucosa and histologically confirmed gastritis. ${ }^{1}$ The question remains, however, as to whether $H$ pylori has a role in the pathogenesis of acute or chronic gastritis or is merely a commensal. ${ }^{2}$ Raised serum perpsinogen (PG) I concentrations are found in about two thirds of adults with peptic ulcer disease $^{3}$ and are thought to be a useful marker of genetic predisposition to ulceration. Serum PG I concentrations have been found to be raised in children with $H$ pylori associated gastritis. ${ }^{4}$ In the same population serum PG I concentrations were related to the severity of gastritis in $H$ pylori positive subjects. ${ }^{5}$ In adults the concentration of serum PG I has been reported to be correlated with histological gastritis associated with the presence of $H$ pylori, and to correlate with the degree of inflammation. ${ }^{6}$ It has also recently been shown that PG I and the PG I:PG II ratio are predictors of antral gastritis. ${ }^{7}$

\section{Methods}

After informed consent had been obtained; gastric biopsy specimens were obtained from 81 consecutive patients (male/female ratio: 43:38) undergoing upper gastrointestinal endoscopy for the investigation of dyspeptic symptoms. Their ages ranged from 17 to 81 (mean 53 years). None of the patients had received any medication which might have affected gastric acidity before endoscopy.

Oesophago-gastroduodenoscopy was performed under local anaesthesia (Xylocaine spray) using an Olympus XQ20 gastroscope. The endoscope and biopsy forceps were disinfected in $2 \%$ glutaraldheyde after each use.

During endoscopy at least eight biopsy specimens (four from the antrum and four from the body) were taken. The specimens were fixed in $10 \%$ buffered formalin, embedded in paraffin wax, sectioned, and stained with haematoxylin and eosin. $H$ pylori were identified by Giemsa staining. Gastritis was classified using criteria described by Whithead $e t a l^{8}$ and modified by Warren and Marshall, ${ }^{9}$ and was made without knowledge of the results of the Giemsa staining or of the serological data. Each specimen was scored as follows: normal $=1$; diffuse chronic inflammatory infiltrate of the lamina propria (regarded as a "quiescent" chronic superficial gastritis) $=2$; mild atrophy $=3$; moderate atrophy $=4$; severe atrophy $=5$.

Venous blood samples were taken for the determination of serum $H$ pylori IgG using an ELISA technique standardised retrospectively and prospectively in more than 2000 patients ${ }^{10}$, with a sensitivity and specificity of up to $94 \% .^{11}$

After an overnight fast, blood was drawn at 9 am and serum PG I and II concentrations were determined by radioimmunoassay (RIA), as described before. ${ }^{12}$

Statistical analysis was done using the two tailed Mann-Witney U-test. Correlations between the serological markers and the degree of antral and body gastritis were assessed by analysis of variance. Correlations among the serological and pathological features and age were calculated using Pearson's correlation test. 
Comparison of variables measured in $H$ pylori positive and negative patients

\begin{tabular}{lccl}
\hline & $\begin{array}{l}\text { H pylori } \\
\text { positive } \\
(n=59)\end{array}$ & $\begin{array}{l}\text { H pylori } \\
\text { negative } \\
(n=22)\end{array}$ & PValue \\
\hline Sex (M/F) (rang) & $32 / 27$ & $11 / 11$ & $\mathrm{NS}$ \\
Age, mean (rane & $56(20-81)$ & $46(17-33)$ & $<0.02$ \\
PG I (ng/ml) (mean (SD)) & $99 \cdot 5(64 \cdot 5)$ & $72 \cdot 4(54 \cdot 5)$ & $<0.001$ \\
PG II (ng/ml) (mean (SD)) & $19 \cdot 3(12 \cdot 0)$ & $8 \cdot 9(7 \cdot 3)$ & $<0.001$ \\
PG I: PG II ratio & $5 \cdot 8(2 \cdot 7)$ & $8 \cdot 8(4 \cdot 5)$ & $<0.001$ \\
IgG (OD 470 nm) & $1199 \cdot 9(168 \cdot 7)$ & $569 \cdot 4(139.9)$ & $<0.001$ \\
Antral grade (1-5) & $2 \cdot 97(0 \cdot 7)$ & $1 \cdot 41(0 \cdot 22)$ & $<0.001$ \\
Body grade (1-5) & $2 \cdot 37(0 \cdot 18)$ & $1 \cdot 41(0 \cdot 22)$ & $<0.001$ \\
\hline
\end{tabular}

\section{Results}

Endoscopic diagnoses were: normal (18 patients); antral gastritis $(n=28)$; gastric ulcer $(n=22)$; and duodenal ulcer $(n=13)$. Fifty nine patients had histological gastritis associated with the presence of $H$ pylori (endoscopic diagnoses: normal in eight patients; antral gastritis in 20; gastric ulcer in 18; and duodenal ulcer in 13). $H$ pylori infection was limited to the antrum in 10 cases and affected both the antrum and the body in 49. In 22 cases without $H$ pylori infection gastritis was found only in four patients with gastric ulcer. Gastritis affected only the antrum in 21 cases, only the body in eight, and both antrum and body in 34 .

$H$ pylori positive patients had significantly higher PG I and PG II concentrations than $H$ pylori negative patients $(\mathrm{n}=22)$ (figure). Although this was significant for both variables, there was a remarkable overlap between the individual values of PG I values in $H$ pylori negative and $H$ pylori positive patients and a smaller overlap of PG II values. The PG I:PG II ratio was significantly lower in $H$ pylori positive than in $H$ pylori negative patients. $H$ pylori positive patients had significantly higher IgG titres than $H$ pylori negative patients (table), with almost no overlap at all between the individual values (figure).

All patients with gastric ulcers had gastritis,
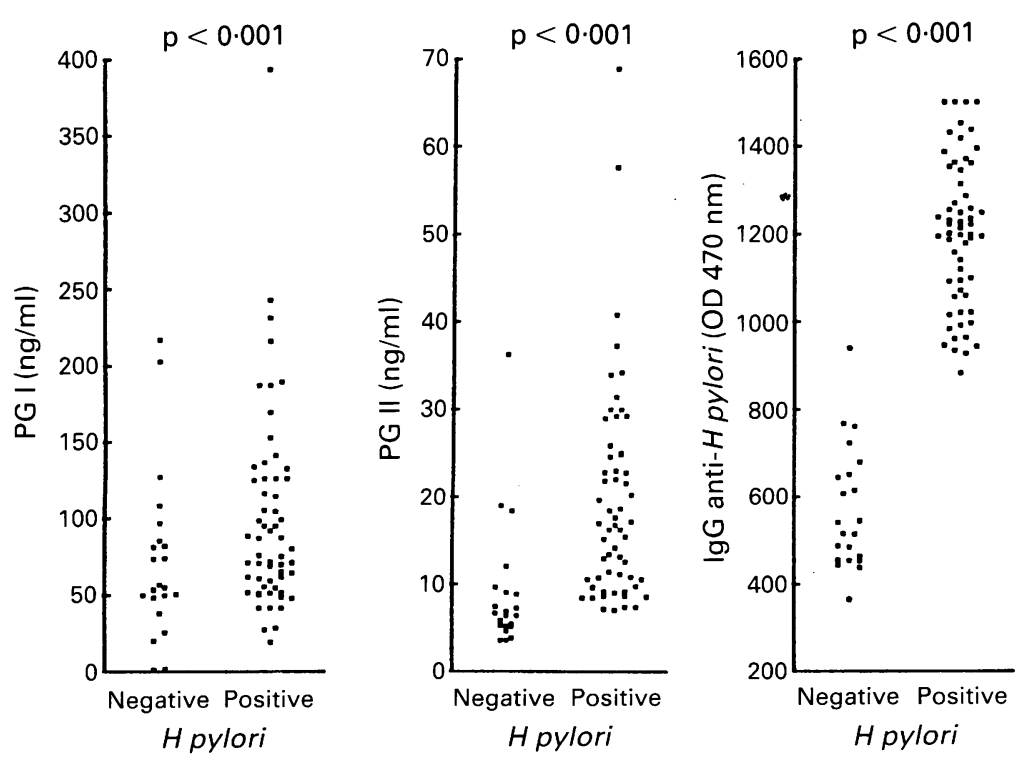

Scatterplot of serum concentrations PG I, PG II, and IgG antibodies to $H$ pylori in $H$ pylori negative and positive patients and $H$ pylori infection was found in 18 of 22 $(82 \%)$ cases. All patients with duodenal ulcers had $H$ pylori positive gastritis. In these subjects the mean (SD) serum PG I concentration was significantly higher than that of $H$ pylori positive patients without duodenal ulcers (130.9 (92.8) v 90.7 (51.9); $\mathrm{p}<0.05)$.

Significant correlations were found between the age of patients and serum PG II concentrations $(R=0.324 ; p<0.01)$, the PG I:PG II ratio ( $R=-0.373, p<0.01)$, IgG titres to $H$ pylori $(\mathrm{R}=0.307, \mathrm{p}<0.01)$, the severity of body gastritis $(R=0.279$, $\mathrm{p}<0.02)$, and $H$ pylori infection $(\mathrm{R}=0.299$, $\mathrm{p}<0.01$ ), and between the degree of gastritis in the body of the stomach and the PG II value $(\mathrm{p}<0.01)$.

\section{Discussion}

Endoscopy may be completely unhelpful in adults with dyspepsia if endoscopic biopsy specimens are not taken routinely. ${ }^{13}$ In our series we confirmed these results. Indeed, almost half of our patients with macroscopically normal endoscopic findings had histological gastritis (eight of 18 , or $44 \%$ ). Moreover, all patients with histologically confirmed gastritis were colonised by $H$ pylori ( $\mathrm{n}$ = 59) except four patients with gastric ulcer. None of the patients without histological evidence of gastritis $(n=22)$ was colonised. All the patients with duodenal ulcers $(n=13)$ were colonised by $H$ pylori; the prevalence in patients with gastric ulcers was $82 \%$ (18 of $22)$. These findings agree with published results. ${ }^{1}$ In humans PG $I$ is produced only in the fundic gland area of the stomach, by chief and mucous neck cells. ${ }^{14}$ PG II is also produced by chief and mucous neck cells, and additionally by pyloric glands in the gastric antrum and Brunners's glands in the proximal duodenum. ${ }^{15}$ The difference in the cellular origins of PG I and PG II is important because changes in their concentrations in serum correlate with certain histological abnormalities in the gastric mucosa.

In this series patients with duodenal ulcers had serum PG I concentrations that were significantly higher than those in $H$ pylori positive patients without duodenal ulcers. This agrees with previous findings. Previous studies have shown that in some families with a prominent history of duodenal ulcer, hyperpepsinogenaemia $I$ is a marker of increased risk for the occurrence of duodenal ulcer. ${ }^{16-18}$ A recent prospective study also found that apparently healthy people with raised serum PG I concentrations are at increased risk of developing duodenal ulcers. ${ }^{19}$

In the light of the finding that virtually all patients with duodenal ulcers are infected with $H$ pylori, however, and the evidence in this and previous studies that $H$ pylori infection is associated with raised values of serum PG I, the hyperpepsinogenaemia in duodenal ulcer could be related to $H$ pylori infection.

In our study serum PG I and PG II concentrations were significantly higher in $H$ pylori positive than in $H$ pylori negative 
patients. We also confirmed that $H$ pylori positive patients have significantly higher IgG antibody titres than $H$ pylori negative patients. Our results seem to indicate that the PG I and PG II values taken together could be considered a predictor of $H$ pylori infection associated with antral gastritis. In accordance with Karnes et $a l,{ }^{7}$ we also found a significantly lower PG I: PG II ratio in $H$ pylori positive patients.

We did find a correlation between the degree of the body gastritis and serum PG II values. Moreover, PG II, IgG antibodies to $H$ pylori, the severity of body gastritis and $H$ pylori status were directly correlated with the age of patients. This agrees with recent observations which suggest that an age related increase of PG in a healthy control population was caused by an increasing prevalence of $H$ pylori infection. ${ }^{20}$ Therefore, the correlation between the severity of the body gastritis and serum PG II concentrations could be due to age related changes in the incidence of body gastritis and $H$ pylori infection.

We suggest that serum pepsinogen I as well as the serum pepsinogen II concentration, together with a fall in the PG I: PG II ratio could be used as predictors of $H$ pylori infection, as well as serum IgG antibodies to $H$ pylori.

1 Vaira D, Holton J, Barbara L. Helicobacter pylori and gastroduodenal disease. Gastroenterol Int 1991;4:70-6.

2 Vaira D, Holton J, Miglioli M, et al. Helicobacter pylori and other spiral organisms in gastroduodenal disease. Curr Op Gastroenterol 1992;8:918-26.

3 Brady CE, Hadfield TL, Hyatt JR, Utts SJ. Acid secretion and serum gastrin levels in individuals with and serum gastrin levels in individuals with

4 Oderda G, Vaira D, Holton J, Dowsett JF, Ansaldi N.
Serum pepsinogen I and IgG antibody to Campylobacter pylori in non-specific abdominal pain in childhood. Gut 1989;30:912-16.

5 Oderda G, Vaira D, Dell'Olio D, et al. Serum pepsinogen $I$ and gastrin concentrations in children positive for Helicobacter pylori. f Clin Pathol 1990;43:762-5.

6 Schoetensack C, Malfertheiner P, Stanescu A, et al. Gastrin and pepsinogen I serum concentration in Campylobacter pylori positive chronic gastritis. In: Megraud F, Lamouliatte H, eds. Gastroduodenal pathology and Campylobacter pylori. London: Elsevier, 1989:565-70.

7 Karnes WE, Samloff IM, Siurala M, et al. Positive serum antibody and negative tissue staining for Helicobacter pylori in subjects with atrophic body gastritis. Gastroenterology 1991;101:167-74.

8 Whitehead R, Truelove SC, Gear MWL. The histological diagnosis of chronic gastritis in fiberoptic gastroscope biopsy specimens. $\mathcal{F}$ Clin Pathol 1972;25:1-11.

9 Marshall BJ, Warren JR. Unidentified curved bacilli in the stomach of patients with gastritis and peptic ulceration. Lancet 1984;i:1311-15.

10 Vaira D, Holton J. Serum immunoglobulin G antibody levels for Campylobacter pylori diagnosis. Gastroenterology 1989;97:1069-70

11 Oderda G, Vaira D, Holton J, et al. Helicobacter pylori in children with peptic ulcer and their families. Dig Dis $S c i$ children with pepti

12 Samloff IM. Pepsinogen I and II. Purification from gastric mucosa and radioimmunoassay in serum. Gastroenterology 1982;82:26-33.

13 Vaira D, Holton J, Osborn J, et al. Use of endoscopy in patients with dyspepsia. $B r$ Med $\mathcal{f} 1989 ; 299: 237$.

14 Samloff IM. Cellular localization of group I pepsinogens in human gastric mucosa by immunofluorescence. Gastroenterology 1971;61:185-8.

15 Samloff IM, Liebman WM. Cellular localization of the group II pepsinogens in human stomach and duodenum by immunofluorescence. Gastroenterology 1973;65: by im 42 .

16 Rotter Л, Sones JW, Samloff IM, et al. Duodenal ulcer disease associated with elevated serum pepsinogen I: an inherited autosomal dominant disorder. $N$ Engl $f$ Med 1979:300:63-5.

17 Rotter JL, Peterson GM, Samloff IM, et al. Genetic heterogeneity of hyperpepsinogenemic I and normopepsinogenemic I duodenal ulcer disease. Ann Intern Med 1979;91:372-7.

18 Taylor IL, Calam J, Rotter JL, et al. Family studies of hypergastrinemic, hyperpepsinogenemic I duodenal ulcer. Ann Intern Med 1981;95:421-5.

19 Samloff IM, Stemmermann GN, Heilbrun LK, Nomura A. Elevated serum pepsinogen I and II levels differ as risk factors for duodenal ulcer and gastric ulcer. Gastroenterology 1986;90:570-6.

20 Vanendaal RA, Biemond I, Pena AS, van Duijn W, Kreuning J, Lamers CBHW. Influence of age and Helicobacter pylori infection on serum pepsinogens in healthy blood transfusion donors. Gut 1992;33:452-5. 